For example, $17.9 \mathrm{mgm}$. sliced lidney cortex (rat) produced in 140 minutes in the presence of

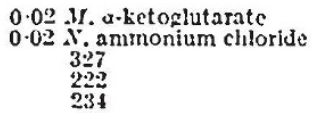

In the presence of molecular oxygen reaction (2) is follorred by reaction (3).

(3) glutamic acid $+\mathrm{fO}_{2}=a$-ketoglutaric acid $+\mathrm{XH}$;

and tho net result of (2) and (3) is the oxidation of ketoglutaric acid to succinic acid and carbon dioxido: COOH.CH, $\cdot \mathrm{CH}_{2} \cdot \mathrm{CO} \cdot \mathrm{COOH}+1 \mathrm{O}_{2}=\mathrm{COOH} \cdot \mathrm{CH}_{2} \cdot \mathrm{CH}_{2} \cdot \mathrm{COOH}+\mathrm{CO}_{2}$. Tho system

glutamic acid $\rightleftharpoons \alpha$-iminoglutaric acid

thus acts as a hydrogen carrier in the oxidation of $\alpha$-ketoglutaric acid. It has been known for somo timo that, in kidnoy, ammonium salts increaso the rate of oxidation of $\alpha$-ketoglutaric acid and of thoso substances which may give riso to the intermediary formation of $\alpha$-ketoglutaric acid, namely, glucoso, lactic acid and pyruvic acid ${ }^{3}, 4$. This may now bo oxplained by the fact that ammonia, according to reaction (2), is required in the oxidation of ketoglutaric acid.

Reaction (2) was not observed in liver, pigeon brain or pigeon breast muscle. Several facts suggest, howover, that glutamic acid (or glutamine) nets as a hydrogen carrier in these tissues also, but it is not yet clear from which substrates the hydrogen is accepted. Isocitric acid ${ }^{5}$ and $\beta$-hydroxybutyric acid ${ }^{6}$ which may donato hydrogen to iminoglutaric acid in artificial enzymo systems do not appear to react in the intact cells.

Department of Biochemistry, University of Sheffield. August 4.

1 Krcls and Jolunson, Biochem. J., 31, 615 (193i).

Knoop and Oesterlin, Z. physiol. Chem., 148, 291 (1925).

Krebs, 2. physiol. Chem., 217, 101 (1933); Klin. Woch., 11, 17tt (1032).

- Edson, Biochem. J., 29, 2032 (1035).

- Adler, von Euler, Gūnther and Plass, Biuchem. .J., 33, 1023 (1939).

- Dewan, Biochem. J., 32, 1378 (1933).

\section{Tarsiers in Captivity}

Sprectual tarsiers havo been maintained in cap. tivity for varying lengths of time by a number of observers ${ }^{1,2,3}$; but only at stations actually within tho area of their geographical distribution (Melanesia). No record has been found of this form reaching the zoological gardens of Europo or North America.

The present note relates to a pair of tarsiers that have been held under laboratory conditions at New Haven, Connecticut, for the past nine months. Theso specimens, § mature femalo and her presumptive offspring, a young inale, wero captured by Mr. J. S. Eckman at Barrio Bad-As, L'rovince of Surigao, N.E. Mindanao, Philippino Islands, in July 1938. Nr. Eckman kept them as pets until October 1938 when, coming to the United States, he brought them at our request to I.os Angeles, California, arriving in mid-November. From thero thoy wero at once shipped by nir to Now York, and wero received at New Haven on Novernber 18, 1938.

These animals have thriven in captivity, in spite of a somewhat less than ideal environment. During the winter the temperature of their room executed fluctuations ranging from $24^{\circ}$ to $30^{\circ} \mathrm{C}$., althuugh wo sought to maintain an average of $28^{\circ} \mathrm{C}$. A crudo humidifier was only partially successful. They aro kept in a basement room with a north-western ex. posure, receivo no sunlight, and only a low intensity of light. They have received, however, about 3 hours light every' other day from a 'Sperti' ultra-violet lamp.

'The only food which thoy havo accepted with absoluto consistency has been mealworms (Tenebrio larva), of which they havo taken somo 50-60 each per day. 'To a dish of this food have been added, every day or so, a littlo salt mixturo and a few drops of cod liver oil. Now-born mico wero eaten, two or threo a day each, for tho first few weeks that wo had tho tarsiers; but theso aro now always refused. Nor will they touch raw beef or liver since becoming accustorned to tho live food, and both fruit and milk. aro always rejected. The weight of the femalo increased rapidly from $161 \mathrm{gm}$. to a maximum of around $208 \mathrm{gm}$.; this probably represents weight regained plus certain fat deposition. Tho weight of the male has increased moro steadily from 106 to $159 \mathrm{gm}$., most of which increaso would appear to represent growth.

'Tho tarsiers aro kept in a largo eago containing a smaller 'hido-out' cage to which they keep for tho greater part of the day, and to which thoy rapidly retreat when frightened. They emerge around 6 p.m. and aro feeding and very active until at least 4 a.m. Their reaction to the ultra-violet light is quito capricious; sometimes thoy como out and bask within a foot of it, at other times they seek to remain hidden.

'The female has been observed to exhibit cyclical swelling of the external genitalia, coupled with a dramatic change in the cellular content of the vagina from the normal inixture of leucocytes and nucleated epithelial cells to completo or almost completo cornification of tho epithelials with partial or complete disappearance of leucocytes. 'The times between tho estimated peaks of theso cycles havo ranged from 23 to 28 days over six such cycles. A sufficiently intensive search for red blood cells in tho vaginal lavage has not yet been made. 'Tho reproductivo stutus of the male, who would now bo somewhat more than a year old, is not known, although erections havo been noticed.

Observations on other aspects of the special physiology and behaviour of the tarsiers are being continued.

Hubeit R. Catchpole. Jons F. Fulto:

Isaboratory of Physiology,

Yale University School of Medicine. Now Haven, Conn. July 17.

' Clirk, I.cGiros, Proc. Zool. Soc. Lond., 217-2:23 (19:21).

*Lwis, G. C., J. IIammol., 20, 57-61 (1939).

2 Cook, S., J. Ifammol., 20, 173-177 (1939).

Formation of Cleistogamic and Chasmogamic Flowers in Wild Violets as a Photoperiodic Response

Is the spring of 1938 , an investigation was undertaken to study experimentally the physiological conditions for cleistogamy in violets. It seemed obvious that the results of $\mathrm{Bergdolt}^{1}$ do not offer a satisfuctory explanation of tho occurrence of this phenomenon in Nature. Nutritional difficulties aro not likely to occur suddenly and so regularly as to account for tho seasonal appearance of cleistogamic and chasmogamic 